\title{
Habitat Differences between Basin and Wyoming
Populations Sagebrush in Contiguous
}

\author{
JERRY R. BARKER AND CYRUS M. MCKELL
}

\begin{abstract}
Basin and Wyoming big sagebrush plants growing in contiguous populations were studied to identify potential habitat differences in plant water and soil relationships. At 3 study sites, basin big sagebrush plants were growing in and adjacent to a drainage, while Wyoming big sagebrush plants occupied areas adjacent to the basin big sagebrush populations. Soil- and leaf-water potentials and leaf-transpiration resistances were measured from May to October 1980 to identify differences between basin and Wyoming big sagebrush plant-water relationships. Soil identification and plant tissue analyses were conducted to help characterize edaphic differences between the subspecies. The results of these studies showed that basin big sagebrush plants grew in a more mesic and fertile habitat than did Wyoming big sagebrush plants. Understanding the environmental differences of these two big sagebrush subspecies is important in effectively managing basin and Wyoming big sagebrush ranges.
\end{abstract}

The woody sagebrushes (subgenus tridentatae (Rhdb.) E.D. McArthur of Artemisia L.) occur naturally only in western North America, ranging from southern Canada to northern Mexico (Beetle 1960, McArthur et al. 1981). The most common, important, and widely distributed species is big sagebrush (Artemisia tridentata Nutt.). Big sagebrush plants are common on about $58,655,000$ hectares from the arid lands of the Great Basin to the moist, cool areas of mountain ranges (Beetle 1960, Hall and Clements 1923, McArthur 1979, Winward 1970).

Considering the wide distribution of big sagebrush, it is not surprising to find genotypic variation among $A$. tridentata populations (Caldwell 1979). Presently, the big sagebrush complex consists of 3 subspecies with 2 forms (Beetle 1960, Beetle and Young

\footnotetext{
Authors are range ecologist, Bio-Resources, Inc., P.O. Box 3447, Logan, Utah 84321 and vice-president for research. Native Plants, Inc. 360 Wakara Way, Salt Lake City, Utah 84101 . Authors acknowledge the assistance of Chris Call and Marianne Barker in collecting field data. The work was supported by the Department of Energy, Utah Agricultural Experiment Station, and Ecology Center, Utah State University, Logan, 84322.

Manuscript received November 10, 1981.
}

1965, McArthur 1979, Winward 1980). According to range scientists the big sagebrush subspecies and forms are habitat specific (McArthur and Plummer 1978, McArthur et al. 1979, Morris et al. 1976, West et al. 1978, Winward 1980, Winward and Tisdale 1977).

General habitat differences between basin (A. tridentata ssp. tridentata) and Wyoming big sagebrush $(A$. tridentata spp. wyomingensis) have been reported in the literature. Basin big sagebrush usually grows in deep, seasonally dry, well-drained, fertile soils on plains, valleys, and foothills between elevations 610-2,140m (McArthur and Plummer 1978, McArthur et al. 1979. Morris et al. 1976, Winward 1980, Winward and Tisdale 1977). In contrast, Wyoming big sagebrush grows in dry, shallow, rocky soils on foothills and valleys between elevations of 1,520-2,150 m (McArthur and Plummber 1978, McArthur et al. 1979, Morris et al. 1976, Winward and Tisdale 1977). Furthermore, Beetle and Young (1965) reported that whenever basin and Wyoming big sagebrush are found close together, the latter subspecies always occupies the drier, poorer, more shallow soils. West et al. (1978), in a biogeographical sagebrush study in Nevada, found that Wyoming big sagebrush occupied soils warmer and drier than did basin big sagebrush.

For the present study, 3 sites were selected where basin and Wyoming big sagebrush grew in contiguous populations. At each site, basin big sagebrush plants grew within and next to a drainage while Wyoming big sagebrush plants occupied adjacent sites. Big sagebrush plant height decreased with distance from the drainages (Barker 1981). Plant height near the drainages averaged about 2.5 $m$ and decreased with distances along an apparent moisture gradient to less than $1.0 \mathrm{~m}$ (Fig. 1).

In considering the difference in plant stature, a logical question arises. Is basin big sagebrush larger than Wyoming big sagebrush in these contiguous populations because of habitat or genetic differences? The research reported herein discusses habitat variation in water and soil relationships between the two subspecies that would partially account for the differences in plant stature. The genetic influence on plant stature is reported in Barker (1981) and 


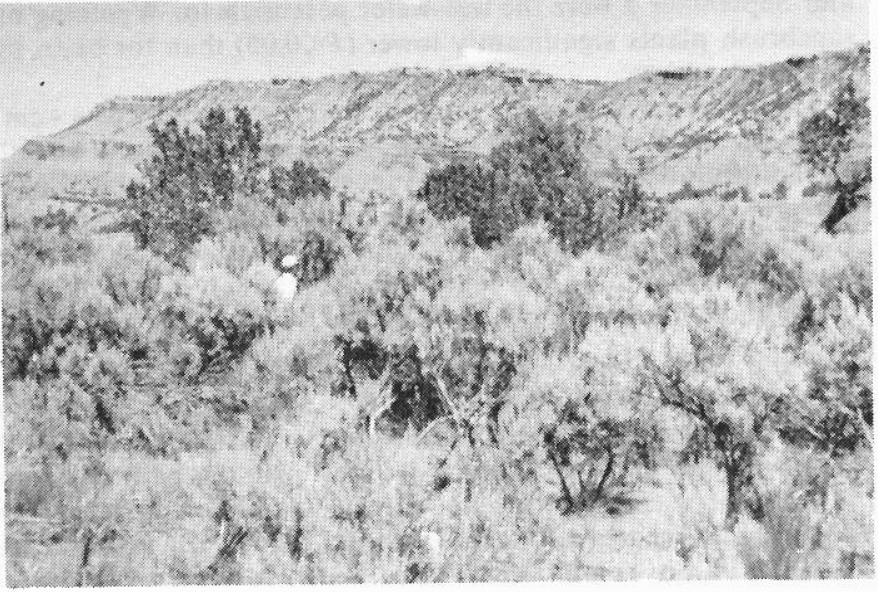

Fig. 1. Decrease in plant height with distance from the gully at the Maeser study site. The large and small plant populations are located in the mesic and xeric habits, respectively.

Barker et al. (1983).

\section{Description of Study Sites}

The Sage Creek study site (N $\left.41^{\circ} 46^{\prime} 36^{\prime \prime}-\mathrm{W} 111^{\circ} 10^{\prime} 11^{\prime \prime}\right)$ is located about $4.8 \mathrm{~km}$ west of Sage Creek Junction on Highway 30 in Rich County in northeastern Utah. Average annual precipitation varies from 25 to $30 \mathrm{~cm}$. The frost-free period ranges between 55 to 65 days (Personal communication, Soil Conservation Service Personnel, Logan, Utah). Elevation is $1,950 \mathrm{~m}$. Slope associated with both the small and the large plants varies from 3 to $4 \%$. The exposure is northerly. Other important plants in the area include low rabbitbrush (Chrysothamnus viscidiflorus), western yarrow (Achillea millefolium), gray horsebrush (Tetradymia canescens), canby bluegrass (Poa canbyi), letterman needle grass (Stipa lettermanii), and slender wheatgrass (Agropvron trachycaulum).

The Greasewood Wash study site (N $\left.41^{\circ} 55^{\prime} 66^{\prime \prime}-\mathrm{W} 108^{\circ} 52^{\prime} 30^{\prime \prime}\right)$ is located about $10.2 \mathrm{~km}$ north of the Jim Bridger Coal Mine along Sweetwater County Road 4-17 in southwestern Wyoming. Average annual precipitation varies from 12 to $22 \mathrm{~cm}$. The frost-free period ranges from 80 to 110 days (Personal communication, Soil Conservation Service Personnel, Rock Springs, Wyo.). The elevation is $2,063 \mathrm{~m}$. The slope of the site varies from 2 to $5 \%$ with a western exposure. Other important plants in the area include bud sage (Artemisia spinescens), gardner saltbush (Atriplex gardneri), low rabbitbrush (Chrysothamnus visiciflorus), thick spike wheatgrass (Agropyron dasystachyum), pacific aster (Aster chilensis), and Great Basin wildrye (Elymus cinereus).

The Maeser study site ( $40^{\circ} 34^{\prime} 11^{\prime \prime}-\mathrm{W} 40^{\circ} 35^{\prime}$ ) is located in the Uinta Basin, $11.2 \mathrm{~km}$ north of Maeser, Utah along Taylor Mountain Road. Average annual precipitation is 25 to $30 \mathrm{~cm}$. The frost-free period ranges between 110 to 140 days (Personal communication, Soil Conservation Service Personnel, Vernal, Utah). Slope of the area is 3 to $4 \%$ with a southern exposure. Elevation is $2,296 \mathrm{~m}$. Other important plants at the study site include shadscale (Atriplex confertifolia), greasewood (Sarcobatus vermiculatus), and rubber rabbitbrush (Chrysothamnus nauseosus).

\section{Methods}

Basin and Wyoming big sagebrush were taxonomically separated based on leaf morphology, current year's growth, twodimensional paper chromatography, and chromosome counts (Barker 1981). Taxonomic keys by McArthur et al. (1979), Winward (1980), and Winward and Tisdale (1977) were also helpful. In addition, subspecies were verified with voucher specimens from each study site. ${ }^{1}$

A. tridentata subspecies voucher specimens were confirmed by Dr. A.H. Winward, regional ecologist, USDA Forest Service, Intermountain Region.

\section{Plant-Water Relationships}

Soil-water potential, leaf-water potential, and leaf-transpiration resistance were measured at each site to compare the various water relations of basin and Wyoming big sagebrush. Five randomly selected plants per population per site were studied. Under each plant on April 28 and 29, 1980, Peltier thermocouple psychrometers (Brown and Collins 1980) were placed at a depth of 30 and 60 $\mathrm{cm}$ to measure soil-water potentials. These depths were selected because they characterize the area where the majority of lateral roots less than $3 \mathrm{~mm}$ in diameter occur (Sturgess 1977). The psychrometers were placed horizontally with good soil contact to reduce the influence of temperature gradients (Wiebe et al. 1977). Soil water potential readings were taken about every 2 weeks from mid-May until September, 1980.

Leaf-water potentials were read immediately after the soil-water potentials were determined (Brown and Collins 1980). The distal $5.0 \mathrm{~mm}$ of 3 to 4 stems (including leaves) per plant were inserted into a sample chamber containing a Peltier psychrometer. To reduce variation, the stem tips were selected from the southern, top-most portion of the plant. Sample chambers were then placed in an ice chest and shaded from the sun for a minimum of 60 minutes to reduce temperature gradients and allow vapor equilibration before readings were made. Stem tips were collected about noon-time each sampling day.

Transpiration-resistance measurements were made on 3 to 4 leaves per plants using a Lambda LI-65 autoporometer. To reduce variation, leaves were selected from the southern, top-most portion of the plant. Readings were made at noon each day. The sensor was placed on the upper surface of the amphistomatous leaves (Diettert 1938) and shaded while the reading was obtained to minimize temperature gradients. Evaluation of these measurements was by two-way analysis of variance and Duncan's new multiple range test (Ott 1977).

\section{Soil and Plant Tissue Analyses}

To identify edaphic differences between basin and Wyoming big sagebrush habitats, soils associated with each population were described and classified according to Soil Conservation Service methods (Soil Survey Staff 1975)². Bulk soil samples were collected from the "A", "B", and "C" horizons of each soil profile for laboratory analyses. Only data for the "A" horizon are reported herein to show edaphic differences (see Barker 1981 for complete soil profile descriptions). Standard analyses for soil classification were performed by the Soils Testing Laboratory, Utah State University.

Vegetal current year's growth was collected September 21, 1979 to determine mineral content of basin and Wyoming big sagebrush. Plant material was obtained from 6 plants per population per site. Percent nitrogen, calcium, magnesium, phosphorus, potassium, and chloride were measured. Also, copper, iron, manganese, zinc, sodium, and boron levels ( $\mathrm{ppm}$ ) were determined. Chemical analyses were performed by the Soils Testing Laboratory, Utah State University. Data were analyzed using two-way analysis of variance and Duncan's new multiple range test (Ott 1977).

\section{Results}

\section{Plant-Water Relationships}

Soil-water potentials, leaf-water potential, and leaftranspiration resistances showed similar trends at each of the three study sites. Therefore, each type of data was grouped together.

Soil-water potentials for basin and Wyoming big sagebrush plants at depths of 30 and $60 \mathrm{~cm}$ averaged around -1 bar for the first and second measurement dates (Fig. 2). After the first 2 weeks of June, soil-water potentials decreased rapidly. The soil-water potentials for Wyoming big sagebrush plants at $30 \mathrm{~cm}$ deep

${ }^{2}$ Soils were described at Sage Creek, Greasewood Wash and Maeser, respectively, by Dr. Alvin R. Southard, Department of Soils and Biometerology, Utah State University, Logan, Utah; Mr. Malvor Ravenhold, soil scientist, Soil Conservation Service, Rock Springs, Wyoming; and Mr. Garth Leishman, soil scientist, USDA Soil Conservation Service, Vernal, Utah. 


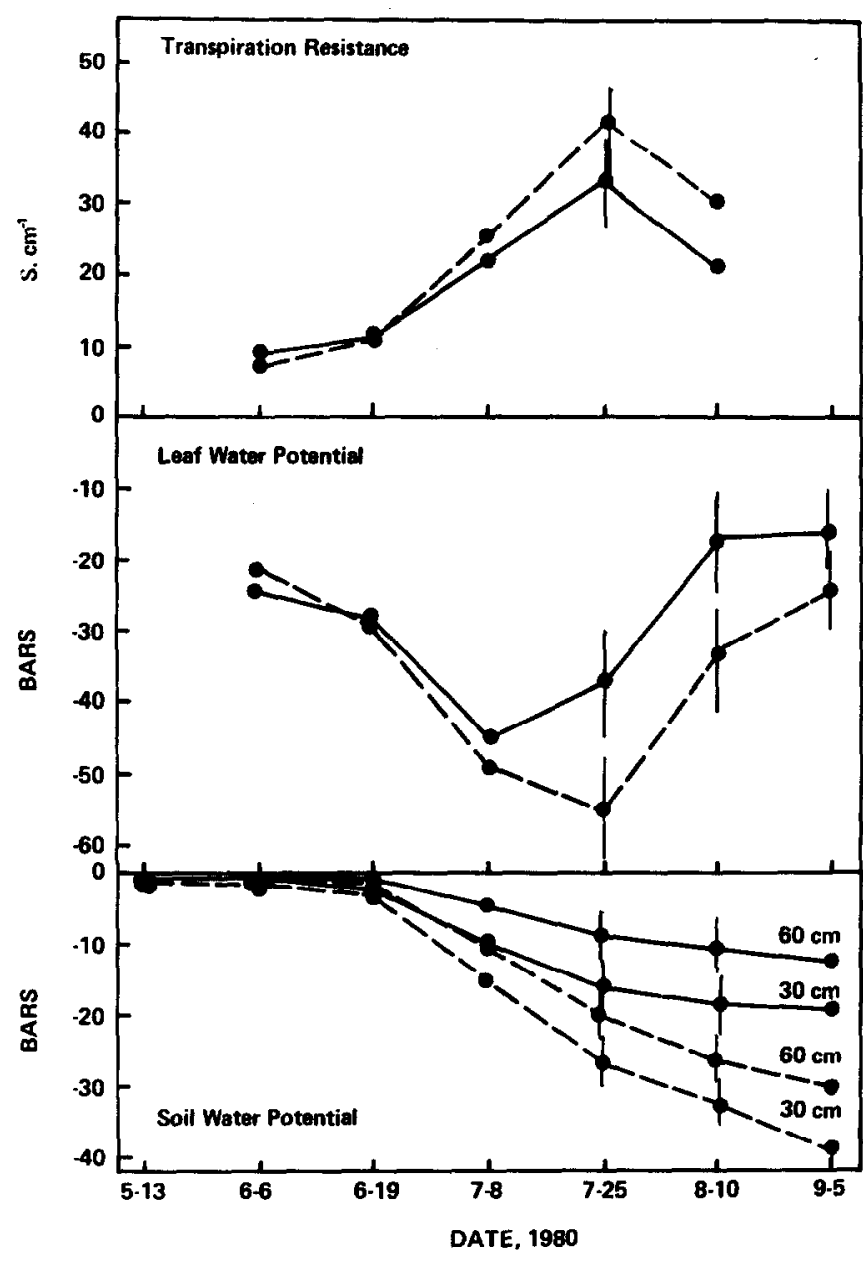

Fig. 2. Transpiration resistance, leaf-water potential, and soil-water potential at a depth of 30 and $60 \mathrm{~cm}$ for basin big sagebrush (- - and Wyoming big sagebrush (--) plants from June to September 1980. Data points were the average of 15 plants. Confidence intervals were formed at the $95 \%$ level.

decreased the fastest. On July 26, August 10 , and September 5 , soil-water potentials under Wyoming big sagebrush plants were significantly lower $(P<0.05)$ than under basin big sagebrush plants. The soil-water potentials were $-23.7,-29.2$, and -34.6 bars for Wyoming big sagebrush plants; and $-13.6,-15.4$ and -16.5 bars for basin big sagebrush plants. Also, on August 10, and September 5 , soil-water potentials at $30 \mathrm{~cm}$ were significantly lower $(P<0.05)$ than at $60 \mathrm{~cm}$ for both subspecies.

Leaf-water potentials for basin and Wyoming big sagebrush plants were -24.2 and -21.1 bars respectively on June 6 (Fig. 2). For basin big sagebrush plants the leaf-water potentials decreased to -45.8 bars on July 8 , after which it increased. The leaf-water potentials for Wyoming big sagebrush plants decreased to -55.8 bars on July 25 and then increased. Only on July 25 , August 10 , and September 5 were the leaf-water potentials for Wyoming big sagebrush plants significantly lower $(P<0.05)$ than for basin big sagebrush plants.

Transpiration resistances on June 6 were 8.46 and $7.85 \mathrm{~s} \cdot \mathrm{cm}^{-1}$ for basin and Wyoming big sagebrush plants respectively on July 25. Transpiration resistances on August 10 were 15.86 and $25.64 \mathrm{~s}$. $\mathrm{cm}^{-1}$ for basin and Wyoming big sagebrush plants, respectively. Even though transpiration resistance values were numerically greater for Wyoming big sagebrush plants than basin big sagebrush plants, these differences were not statistically significant.

\section{Soil and Plant Tissue Analyses}

The chemical and physical analyses showed that there were differences between soils of basin and Wyoming big sagebrush plants (Tables 1 and 2). Soils associated with the basin big sagebrush plants were Torrifluvents at each site. Soils associated with Wyoming big sagebrush were Haplargid, Camborthid, and Torrifluvent at Sage creek, Greasewood Wash, and Maeser, respectively. Soils associated with basin big sagebrush plants had higher organic carbon, nitrogen, water holding capacity, cation exchange capacity, potassium, and phosphorus than the soils associated with Wyoming big sagebrush plants.

There were no physical barriers to root growth in the soils with the exception of the Haplargid soil at Sage Creek. At this site, a calcic horizon was discovered at $30-40 \mathrm{~cm}$, which appeared to restrict root penetration.

Vegetal mineral content of current year's growth varied between the 2 subspecies for several nutrients (Table 3). Basin big sagebrush plants had a significantly greater content $(P<0.05)$ of nitrogen, magnesium, phosphorus, potassium, and zinc. On the other hand, Wyoming big sagebrush contained significantly $(P<0.05)$ more iron.

\section{Discussion}

According to the plant-water relationship study, seasonal differences in soil-water a pparently exist to condition plant development and segregation into separate populations. During 1980, Wyoming big sagebrush plants experienced greater drought conditions than basin big sagebrush. The difference in soil-water potentials indicates that basin big sagebrush plants grew in a more mesic habitat than did Wyoming big sagebrush. The drainages may have been responsible for concentrating water where basin big sagebrush plants grew. After a thunderstorm, July 1979, standing water remained in the drainage at Greasewood Wash for about 1 week.

Both leaf-water potential and transpiration resistance are influenced by the soil-water status (Kramer 1969). As soil-water potential decreases, leaf-water potential decreases and leaf-transpiration resistance increases. Leaves with low water potentials and high transpiration resistances indicate a plant suffering from water stress. Both of these parameters suggest that Wyoming big sagebrush plants experienced a greater water stress than basin big sagebrush plants. The results of this study support earlier suggestions that Wyoming big sagebrush plants tolerate drier soil conditions than basin big sagebrush (Beetle and Young 1965, McArthur 1979, Morris et al. 1976, Tisdale et al. 1969, West et al. 1978,

Table 1. Soil classification at the Sage Creek, Greasewood Wash, and Maeser study sites.

Site habitat $\quad$ Soil family

\section{Sage Creek}

Basin big sagebrush

Wyoming big sagebrush

Greasewood Wash

Basin big sagebrush

Wyoming big sagebrush

Maeser

Basin big sagebrush

Wyoming big sagebrush fine-silty, mixed, frigid Xeric Torrifluvent

fine-silty, mixed (calcareous), frigid Typic Haplargid

fine-loamy, mixed (calcareous), frigid Xerollic Torrifluvent

fine-loamy, mixed (calcareous), frigid Typic Camborthid 
Table 2. Depth, fertility, and moisture characteristics of bulk samples from the " $A$ "horizon for soils associated with basin and Wyoming big sagebrush plants at Sage Creek, Greasewood Wash, and Maeser.

\begin{tabular}{|c|c|c|c|c|c|c|c|c|c|}
\hline \multirow[b]{3}{*}{ Site soil description } & \multirow[b]{3}{*}{ Big sagebrush subspecies } & \multirow{3}{*}{$\begin{array}{l}\text { Depth } \\
\text { (cm) }\end{array}$} & \multirow{2}{*}{\multicolumn{5}{|c|}{ Fertility ${ }^{\prime}$}} & \multicolumn{2}{|c|}{ Moisture } \\
\hline & & & & & & & & $1 / 3$ amos. & 15 amos \\
\hline & & & OC & $\mathbf{N}$ & $\mathbf{P}$ & $\mathbf{K}$ & CEC & $(\%)$ & $(\%)$ \\
\hline $\begin{array}{l}\text { Sage Creek } \\
\text { Torrifluvent } \\
\text { Haplargid }\end{array}$ & $\begin{array}{l}\text { Basin } \\
\text { Wyoming }\end{array}$ & $\begin{array}{l}30 \\
20\end{array}$ & $\begin{array}{l}2.3 \\
1.7\end{array}$ & $\begin{array}{l}0.25 \\
0.19\end{array}$ & $\begin{array}{r}20.2 \\
6.8\end{array}$ & $\begin{array}{l}2.5 \\
1.3\end{array}$ & $\begin{array}{l}20.8 \\
16.5\end{array}$ & $\begin{array}{l}27.2 \\
20.1\end{array}$ & $\begin{array}{l}12.2 \\
10.2\end{array}$ \\
\hline $\begin{array}{l}\text { Greasewood Wash } \\
\text { Torrifluvent } \\
\text { Camborthid }\end{array}$ & $\begin{array}{l}\text { Basin } \\
\text { Wyoming }\end{array}$ & $\begin{array}{l}6 \\
5\end{array}$ & $\begin{array}{l}2.8 \\
1.2\end{array}$ & $\begin{array}{l}0.25 \\
0.11\end{array}$ & $\begin{array}{l}54.0 \\
22.0\end{array}$ & $\begin{array}{l}1.5 \\
0.5\end{array}$ & $\begin{array}{l}17.7 \\
12.8\end{array}$ & $\begin{array}{l}30.5 \\
22.2\end{array}$ & $\begin{array}{r}11.7 \\
8.6\end{array}$ \\
\hline $\begin{array}{l}\text { Maeser } \\
\text { Torrifluvent } \\
\text { Torrifluvent }\end{array}$ & $\begin{array}{l}\text { Basin } \\
\text { Wyoming }\end{array}$ & $\begin{array}{l}10 \\
13\end{array}$ & $\begin{array}{l}1.8 \\
1.1\end{array}$ & $\begin{array}{l}0.19 \\
0.12\end{array}$ & $\begin{array}{l}64.0 \\
21.0\end{array}$ & $\begin{array}{l}1.7 \\
1.0\end{array}$ & $\begin{array}{r}10.7 \\
7.2\end{array}$ & $\begin{array}{l}19.8 \\
17.6\end{array}$ & $\begin{array}{l}7.6 \\
6.0\end{array}$ \\
\hline
\end{tabular}

Winward 1980, Winward and Tisdale 1977).

The taxonomy of the soils suggest long-term diffe rences in plant, soil-water relationships between basin and Wyoming sagebrush habitats. Soils associated with basin big sagebrush plants are Torrifluvents. These are Entisols that were formed by water deposited sediments and a re flooded, but not frequently. On the other hand, the soils associated with Wyoming big sagebrush plants at Sage Creek and Greasewood Wash are Haplargid and Camborthid, respectively. Both Haplargid and Camborthid are Aridisols which are characteristically dry (Soil Survey Staff 1975).

In addition to the apparent soil moisture gradients, there are differences in the level of soil organic matter and fertility between the soils associated with the two subspecies. Soils associated with basin big sagebrush plants have higher organic carbon, nitrogen, cation exchange capacity, potassium, and phosphorus than do soils associated with Wyoming big sagebrush plants. However, these differences may have occurred in response to differences in site productivity sustained by favorable soil water. In general, soils associated with basin big sagebrush plants are fertile and arable (Fireman and Hayward 1952, Wallace and Romney 1972, Winward 1980).

Analyses of vegetal current year's growth of basin and Wyoming big sagebrush showed that mineral content appeared to be in the same range as data reported in the literature (Fairchild and Brotherson 1980, Gough and Erdman 1980, Mayland and Murray 1979, Wallace and Romney 1972) From an animal nutritional aspect,

Table 3. Mineral content of vegetal annual growth for basin and Wyoming big sagebrush plants. 1

\begin{tabular}{lcc}
\hline \hline Mineral & \multicolumn{1}{c}{ Basin big sagebrush } & Wyoming big sagebrush \\
\hline & $-1 . \%$, oven dried weight $-1.73 \mathrm{~b}$ \\
$\mathrm{~N}$ & $1.98 \mathrm{a}$ & $0.38 \mathrm{a}$ \\
$\mathrm{Ca}$ & $0.41 \mathrm{a}$ & $0.16 \mathrm{~b}$ \\
$\mathrm{Mg}$ & $0.18 \mathrm{a}$ & $0.27 \mathrm{~b}$ \\
$\mathrm{~K}$ & $0.33 \mathrm{a}$ & $1.48 \mathrm{~b}$ \\
$\mathrm{Cl}$ & $1.62 \mathrm{a}$ & $0.23 \mathrm{a}$ \\
& $0.25 \mathrm{a}$ & \\
$\mathrm{Cu}$ & & \\
$\mathrm{Fe}$ & & $19.6 \mathrm{a}$ \\
$\mathrm{Mn}$ & $22.7 \mathrm{a}$ & $171.4 \mathrm{~b}$ \\
$\mathrm{Zn}$ & $121.2 \mathrm{a}$ & $44.2 \mathrm{a}$ \\
$\mathrm{Na}$ & $42.8 \mathrm{a}$ & $20.0 \mathrm{~b}$ \\
$\mathrm{~B}$ & $30.7 \mathrm{a}$ & $45.8 \mathrm{a}$ \\
& $52.6 \mathrm{a}$ & $11.8 \mathrm{a}$ \\
\hline
\end{tabular}

IEach mean was the average of 18 plants. Those means that are followed by the same letter for each mineral were not significantly different $(P<0.05)$. basin big sagebrush plants do have a higher forage quality than Wyoming big sagebrush plants. Welch and McArthur (1979) showed that during winter months basin big sagebrush plants contained significantly higher levels of crude protein than Wyoming big sagebrush.

Even though the basin sagebrush habitat is more favorable for plant growth than the Wyoming big sagebrush habitat, genetic differences between the subspecies cannot be ignored when comparing growth variation. Barker (1981) found polyploidy, chromatographic and growth rate differences between basin and Wyoming sagebrush plants at the same 3 study sites. In addition, McArthur and Welch (1982) reported that basin big sagebrush has a greater growth potential than Wyoming big sagebrush. Other researchers have also documented genetic variation between basin and Wyoming big sagebrush (Beetle and Young 1965, McArthur et al. 1981, Winward and Tisdale 1977).

\section{Summary and Conclusion}

Basin and Wyoming big sagebrush plants growing in contiguous populations were studied to identify habitat differences in plant water, soil, and tissue mineral relationships. The results of these studies show that basin big sagebrush plants grow in a more mesic and fertile habitat than do Wyoming big sagebrush plants when found in contiguous populations. As a result, site conditions should be considered when selecting big sagebrush subspecies for range improvement projects such as wildlife habitat improvement, soil stabilization and mined-land rehabilitation (Plummer 1977, Plummer et al. 1968). For such improvement projects to be successful, big sagebrush subspecies and ecotypes should be selected that are adapted to the environmental conditions of the site.

\section{Literature Cited}

Barker, J.R. 1981. Genetic differences between large and small Artemisia tridentata plants in contiguous populations. PhD Diss., Utah State Univ., Logan.

Barker, J.R., C.M. McKell, and G.A. Van Epps. 1983. Shrub largeness: A case study of big sagebrush. p. 35-45 In: K.L. Johnson(ed.). Proceedings of the First Utah Shrub Ecology Workshop. College of Natural Resources, Utah State University, Logan.

Beetle, A.A. 1960. A study of sagebrush, the section Tridentatae of $\mathrm{Ar}$ temisia. Bull. Univ. Wyoming Exp. Sta. 368:1-83.

Beetle, A.A., and A. Young. 1965. A third subspecies in the Artemisia tridentata complex. Rhodora 67:405-406.

Brown, R.W., and J.M. Collins. 1980. A screen-caged thermocouple psychrometer and calibration chamber for measurements of plants and soil water potential. Agron. J. 72:851-854.

Caldwell, M.M 1979. Physiology of sagebrush p. 74-85. In: The Sagebrush ecosystem: A symposium. Utah State Univ., College of Natural Resources, Logan, Utah. 
Diettert, R.A. 1938. The morphology of Artemisia tridentata Nutt. Lloydia 1:3-74.

Fairchild, J.A., and J.D. Brotherson. 1980. Microhabitat relationships of six major shrubs in Navajo National Monument, Arizona. J. Range Manage. 33:150-156.

Fireman, M., and H.E. Hayward. 1952. Indicator significance of some shrubs in the Escalante Desert, Utah. Bot. Gaz. 114:143-155.

Gough, L.P., and J.A. Erdman. 1980. Seasonal differences in the element content of Wyoming big sagebrush. J. Range Manage. 33:374-378.

Hall, H.M., and F.E. Clements. 1923. The phylogenetics method in taxonomy. The North American species of Artemisia, Chrysothamnus, and Atriplex. Publ. Carnegie Inst. Wash. 321:1-355.

Kramer, P.M. 1969. Plant and soil water relationships: A modern synthesis. McGraw-Hill Book Company, New York.

Mayland, H.F., and R.B. Murray. 1979. Mineral-cycling aspects within the sagebrush ecosystem. p. 62-73. In: The sagebrush ecosystem: A symposium. Utah State Univ., College of Natural Resources, Logan, Utah.

McArthur, E.D. 1979. Sagebrush systematics and evolution. p. 14-22. In: The sagebrush ecosystem: A symposium. Utah State Univ., College of Natural Resources, Logan, Utah.

McArthur, E.D., and A.P. Plummer. 1978. Biogeographical and management of native western shrubs. A case study, section Tridentatae of Artemisia. p. 229-241. In: Intermountain biogeography: A symposium, Great Basin Nat. Mem. No. 2.

Mc Arthur, E.D., A.C. Blauer, A.P. Plummer, and R. Stevens. 1979. Characteristics and hybridization of important Intermountain shrubs III. Sunflower family. USDA Forest Serv. Res. Pap. INT-220, Intermt. Forest and Range Exp. Sta., Ogden, Utah.

McArthur, E.D., E.L. Pope, and D.C. Freeman. 1981. Chromosomal studies of subgenus Tridentatae of Artemisia. Evidence for autopolyploidy. Amer. J. Bot. 68:589-605.

McArthur, E.D., and B.L. Welch. 1982. Growth rate differences among big sagebrush (Artemisia tridentata) accessions and subspecies. J. Range Manage. 35:396-401.
Morris, M.S., R.G. Kelsey, and D. Griggs. 1976. The geographic and ecological distribution of big sagebrush and other woody Artemisia in Montana. Proc. Montana Acad. Sci. 36:56-79.

Ott, L. 1977. An introduction to statistical methods and data analysis. Duxbury Press, North Scituate, Mass.

Plummer, A.P., 1977. Revegetation of disturbed Intermountain areas sites. p. 302-339. In: J.L. Thames, (ed.), Reclamation of disturbed lands in the Southwest, Univ. Arizona Press, Tucson.

Plummer, A.P., D.R. Christensen, and S.B. Monsen. 1968. Restoring big game range in Utah. Utah Div. Fish and Game Pub. 68-3. Salt Lake City. Soll Survey Staff. 1975. Soil taxonomy. USDA, Agr. Handbook No. 436. Sturgess, D.L. 1977. Soil water withdrawal and root characteristics of big sagebrush Amer. Midl. Natur, 98:257-274.

Tisdale, E.W., M. Hironaka, and M.A. Fosberg. 1969. The sagebrush region in Idaho. Univ. Idaho Agr. Exp. Sta. Bull. 512, Moscow.

Wallace, A., and E.M. Romney. 1972. Radio ecology and ecophysiology of desert plants at the Nevada test site. U.S. Atomic Energy Commission, TID-25954.

Welch, B.L., and E.D. McArthur. 1979. Variation in winter levels of crude protein among Artemisia tridentata subspecies grown in a uniform garden. J. Range Manage. 32:467-469.

West, N.E., R.J. Tausch, K.H. Rea, and P.T. Tueller. 1978. Taxonomic determination, distribution, and ecological indicator values of sagebrush within the pinyon-juniper woodlands of the Great Basin. J. Range Manage. $31: 87-92$.

Wiebe, H.H., R.W. Brown, and J.R. Barker. 1977. Temperature gradient effects of in situ hygrometer measurements of water potential. Agron. J. 69:933-939.

Winward, A.H. 1970. Taxonomic and ecological relationships of the big sagebrush complex in Idaho. PhD Dis. Univ. Idaho Moscow.

Winward, A.H. 1980. Taxonomy and ecology of sagebrush in Oregon. Oregon State Univ. Agr. Exp. Sta. Bull. 642, Corvallis.

Winward, A.H., and E.W. Tisdale. 1977. Taxonomy of the Artemisia tridentata complex in Idaho. Univ. Idaho, Forest, Wildlife and Range Exp. Sta. Bull. No. 15, Moscow.

\section{Call for Associate Editors}

Volunteers are needed to replace associate editors whose terms will expire in February, 1984. The term of office for associate editors is 2 years, with an optional 2 years in addition. Associate editors have the responsibility of directing the review process in designated manuscripts and of making the decision as to acceptance of papers.

Applicants should send the following information to the Editor, Journal of Range Management, 2760 West Fifth Avenue, Denver, CO 80204: (a) Name, address, and telephone number; (b) Areas of expertise; (c) Brief description of experience in reviewing manuscripts; (d) Titles of 2 or 3 representative papers that they have published. Applications should reach the Editor by November 15, 1983.

Associate editors play a crucial role in developing and maintaining a high-quality professional journal. The Journal in turn reflects the caliber of the members of the Society and the profession. It is hoped that qualified persons will never be lacking to share the burden and the honor of associate editorship. For additional information, contact, Patricia Smith at the Society headquarters (303) 571-0174. 